\title{
Assessment of the Present State and Economical Prospects of Solid Waste at Amin Bazar Waste Dumping Site, Dhaka, Bangladesh
}

\author{
M. S. Islam , A. Sultana ${ }^{1}$, M. Rasheduzzaman', G. K. Kundu ${ }^{3}$, A. K. I. Kamal ${ }^{4}$, M. K. Uddin ${ }^{4}$ * \\ ${ }^{1}$ Department of Environmental Biology and Chemistry, Graduate School of Science and \\ Engineering for Research, University of Toyama, Gofuku 3190, Toyama 930-8555, Japan \\ ${ }^{2}$ Department of Ecosystem Studies, The University of Shiga Prefecture, 2500, Hikone City, Shiga \\ 522-8533 Japan \\ ${ }^{3}$ Department of Fisheries, University of Dhaka, Dhaka, Bangladesh \\ ${ }^{4}$ Department of Environmental Sciences, Jahangirnagar University, Dhaka, Bangladesh
}

Received 18 May 2015, accepted in final revised form 23 June 2015

\begin{abstract}
The study was conducted to explore the current status and the economical prospect of the solid waste management at Amin Bazar waste dumping site, Dhaka. A total of 48 solid waste samples were collected in both dry and wet season to study the physical composition, $\mathrm{pH}$ and moisture content of discarded wastes. The wastes were comprised of plastics (6\%), paper (3.5\%), glass $(0.23 \%)$, garden waste $(8.5 \%)$, food stuffs $(72.25 \%)$, metals $(0.16 \%)$ and textile products $(3.25 \%)$. The $\mathrm{pH}$ values of the samples ranged from 6.9 to 7.8 which indicated the neutral condition. Larger portion of the wastes was organic (72\%). About $14.38 \%$ of wastes were recyclable but there was no recycling and composting facility. Proper recycling of the solid wastes at Amin Bazar can be a source of compost and useful metal resources which may contribute in safe and sustainable environmental management.
\end{abstract}

Keywords: Landfill; Solid waste; Waste management; Recycling; Composting.

(c) 2015 JSR Publications. ISSN: 2070-0237 (Print); 2070-0245 (Online). All rights reserved.

doi: http://dx.doi.org/10.3329/jsr.v7i3.23415 J. Sci. Res. 7 (3), 129-137 (2015)

\section{Introduction}

Rapid urbanization is enlarging the size of cities like Dhaka City in terms of geographical area and population as a process of development. Urban population growth and economic development accelerate the consumption rates and as a result increase the waste generation in developing countries [1]. The increased municipal solid waste (MSW) is causing severe environmental degradation. Residences, commercial establishments, and

\footnotetext{
Corresponding author: khabir88@yahoo.com
} 
institutions, industrial and agricultural activities are the principal sources of solid wastes. Different factors such as spiraling urban population, economic development, consumption pattern, climate, culture and institutional framework play significant role in MSW generation [2]. Solid waste consist highly heterogeneous mass of discarded materials from the urban community. MSW generation was identified as an inevitable consequence of production and consumption activities related to the level of income and urbanization [2]. Solid waste disposal in unscientific way can cause adverse impact on all components of the environment and human health $[3,4]$. Therefore, in order to ensure the longevity of environment the management of municipal solid waste needs to be revamped [5]. Open dumping; sanitary land filling, incineration and composting are the most prominent disposal methods in various parts of the world. Most of the industrialized countries dispose their solid waste in sanitary landfill but scenarios are different in the developing countries like Bangladesh as open dumping is very common here. In Bangladesh there is no ideal management plan for the proper management of huge quantity of solid wastes in most of the big cities. A minor amount of the generated wastes are collected by door-todoor collection system and the major portion of population does not get waste collection services. Nevertheless, MSW management system is still in developing stage due to lack of motivation, awareness, commitment, expertise as well as money and a considerable portion (40-60\%) of wastes are not properly stored, collected or disposed [6,7]. In the major cities of the country, per capita solid waste generation is about $0.5 \mathrm{~kg} /$ day whereas only $0.2 \mathrm{~kg} /$ day of them is carried to the final disposal and rest is disposed-off locally due to the poor waste management system [8]. In response to the excessive growth in population and solid waste generation in developing countries like Bangladesh need an easily and economically feasible waste management system that can effectively address and manage solid wastes [9].

Dhaka, the capital city of Bangladesh is estimated to generate around 3500 to 4500 tons of MSW every day [10]. Most of the generated wastes are dumped on streets, water bodies and other public areas. The wastes dumped into the water bodies clogged the drainage system and contaminate the water. This improper dumping of solid wastes makes serious environmental degradation and public-health risk to the people living in this city. The Dhaka City Corporation (DCC) is the main responsible authority for solid waste management of Dhaka city. DCC, with its limited resources and a poor management plan is facing serious problems in providing a satisfactory service to the city dwellers. An inadequate information base (regarding quantity, type and characteristics of wastes), poor operation and maintenance of service facilities and above all lack of civic awareness on the part of a section of the population are adding up to the deteriorating environmental situation [11].

The aim of the present study was to investigate the solid waste generation, characteristics and management scenario at Amin Bazar waste dumping site, Dhaka. The study also investigated the economical prospects of these solid wastes with proper recycling and composting systems. 


\section{Experimental}

\subsection{Study area}

The Amin Bazar waste dumping site (234ㄴ $48^{\prime \prime} \mathrm{N}$ and $\left.90^{\circ} 17^{\prime} 50^{\prime \prime} \mathrm{E}\right)$, one of the main dumping sites for Dhaka city wastes, is situated within the low-lying floodplain of the River Karanachhali in Savar upazilla under the district of Dhaka alongside Dhaka-Aricha highway. The area around the dumping site is mainly used for agricultural activities and by brick manufacturing industries except during the monsoon (June-October) when the areas are inundated by rain and flood. The area is used as a dumping site from 2007. Fig. 1 shows the study area.

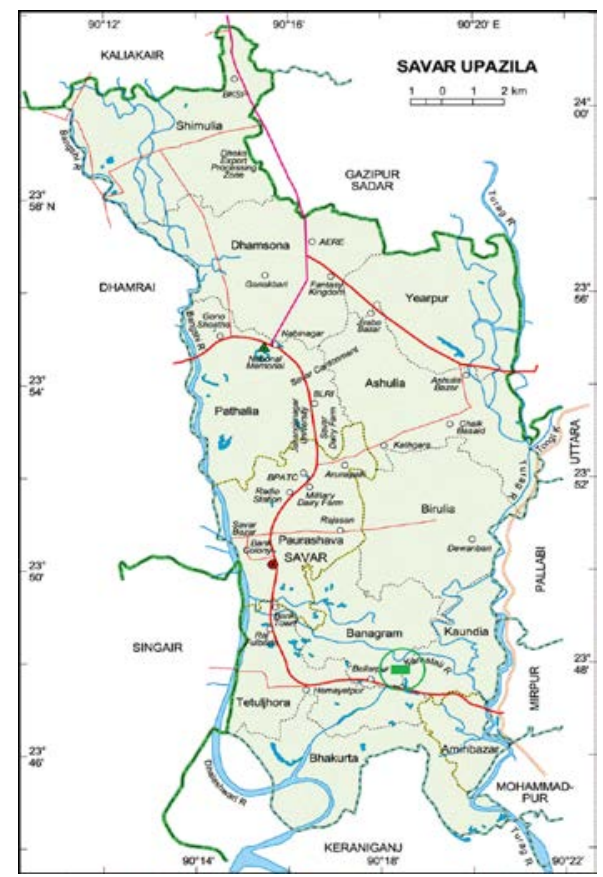

Fig. 1. Location map of the study area. The green shaded area enclosed by circle indicates the waste dumping site.

\subsection{Sample collection and preservation}

The samples were collected in both dry (October to December) and wet season (May to July) in three shifts. Twenty four solid waste samples were collected from the landfill site in each season. The samples were collected from the surface level in clean dry polythene bag and preserved for laboratory analysis. Each of the samples contained approximately 2 Kg of solid wastes. 


\subsection{Sample preparation}

Determination of organic and inorganic composition as well as the recyclable materials was the objectives and therefore the collected samples are prepared for composition analysis, $\mathrm{pH}$ measurement and moisture content. The collected solid waste samples were first dried under the sun for time as much as it needed to be fully dry after that the samples were kept in the laboratory at room temperature. These samples were then used to analyze the physical composition, $\mathrm{pH}$ and moisture content.

\subsection{Sample analysis}

For physical composition analysis, a powerful magnifying glass was used in order to locate every individual particles present in the samples. After careful observations the different particles of the wastes were separated from the samples according to the size. Every element was carefully separated using forceps. Hand gloves were wore to avoid direct contact to skin. After that, the separated particles were weighed by an electronic balance and the measurements were recorded.

For $\mathrm{pH}$ measurement, the sun dried samples were grinded in a mortar and then the powdered samples were taken in a clean vessel and deionized water was added. A total of 40.0 g solid waste powder was added into $100 \mathrm{~mL}$ distilled water. The suspension was stirred several times for $30 \mathrm{~min}$. Then the $\mathrm{pH}$ was measured by the pre-calibrated $\mathrm{pH}$ meter (SCHOTT instrument, model: lab 851) and recorded.

The moisture content of solid waste was determined by a microwave oven using the following formula.

$$
\text { Moisture content, MC (\%) }=\frac{\mathrm{W}_{\mathrm{W}} \times 100}{\mathrm{~W}_{\mathrm{DRY}}}
$$

Where,

$$
\begin{aligned}
& \text { Weight of wet sample and tare }(\mathrm{g})=\mathrm{W}_{\mathrm{WET}+\mathrm{C}} \\
& \text { Weight of dry sample and tare }(\mathrm{g})=\mathrm{W}_{\mathrm{DRY}+\mathrm{C}} \\
& \text { Weight of tare }(\mathrm{g})=\mathrm{W}_{\mathrm{C}} \\
& \text { Weight of water }(\mathrm{g}), \mathrm{W}_{\mathrm{W}}=\left(\mathrm{W}_{\mathrm{WET}+\mathrm{C}}-\mathrm{W}_{\mathrm{C}}\right)-\left(\mathrm{W}_{\mathrm{DRY}+\mathrm{C}}-\mathrm{W}_{\mathrm{C}}\right)
\end{aligned}
$$

\section{Results and Discussion}

\subsection{Amount of incoming solid waste}

The dumping site received waste from the ward no. 9, 10,11,12, 14, 16, and 41 and belonged to the zones $6,7,8,9$ of DCC. The average incoming waste to disposal sites varied from 313 ton/day in dry season to 414 ton/day in wet season as shown in Table 1. 
Table 1. Average incoming waste amount to disposal site in Amin Bazar.

\begin{tabular}{ccc}
\hline Survey time & $\begin{array}{c}\text { Waste amount } \\
\text { carried (ton/day) }\end{array}$ & $\begin{array}{c}\text { Annual Waste amount } \\
\text { carried (ton/year) }\end{array}$ \\
\hline Dry season & 330 & 120450 \\
Wet season & 424 & 154760 \\
Average & 377 & 137605 \\
\hline
\end{tabular}

Total amount of incoming waste is about 137605 ton/year. Around $72 \%$ of the incoming wastes are organic in composition and rests of them (28\%) are inorganic. Waste that arises from living things, decomposes naturally was called organic waste e.g. vegetable, peel of fruits, leaves, flowers, fish and meat, paper, cloth etc. Waste that is not organic, does not decompose and can usually be reused was called inorganic waste. For example, plastic, glass products, metal/iron etc. Most of the organic waste can be reused through composting and the inorganic waste can be recycled.

\subsection{Physical composition}

One of the common features of collected samples was color and odor. All the samples had nauseating bad smell and were black in color. The percentages of the sample composition were varied in different seasons. In the following Table 2, the average percentages of the physical composition and the average amount of recyclability of incoming solid waste at the dumping site are given.

Table 2. Physical Composition and the amount of Recyclable and Non-Recyclable wastes.

\begin{tabular}{|c|c|c|c|c|c|c|}
\hline \multirow[b]{2}{*}{ Constituents } & \multicolumn{3}{|c|}{$\%$ of total waste } & \multirow{2}{*}{$\begin{array}{c}\text { Recyclable/ } \\
\text { Non-Recyclable }\end{array}$} & \multirow{2}{*}{$\begin{array}{l}\text { Recyclable } \\
\text { waste } \\
\text { (tons/year) }\end{array}$} & \multirow{2}{*}{$\begin{array}{c}\text { Non- } \\
\text { recyclable } \\
\text { waste } \\
\text { (tons/year) }\end{array}$} \\
\hline & $\begin{array}{c}\text { Dry } \\
\text { Season }\end{array}$ & $\begin{array}{c}\text { Wet } \\
\text { Season }\end{array}$ & Mean & & & \\
\hline Plastics & 5.00 & 7.00 & 6.00 & Recyclable & 8256 & Nil \\
\hline Paper & 4.00 & 3.00 & 3.50 & Recyclable & 4816 & Nil \\
\hline Glass & 0.25 & 0.20 & 0.23 & Recyclable & 344 & Nil \\
\hline Textile & 3.00 & 3.50 & 3.25 & Non-Recyclable & Nil & 4472 \\
\hline Food and kitchen & 70.00 & 75.00 & 72.25 & Non-Recyclable & Nil & 99763 \\
\hline Wood/grass & 0.16 & 0.10 & 0.13 & Non-Recyclable & Nil & 179 \\
\hline Garden waste & 11.0 & 6.00 & 8.50 & Non-Recyclable & Nil & 11696 \\
\hline Ash/Soil & 1.46 & 1.00 & 1.23 & Non-Recyclable & Nil & 1692 \\
\hline Metals & 0.13 & 0.20 & 0.16 & Recyclable & 196 & Nil \\
\hline Others & 5.00 & 4.00 & 4.50 & Recyclable & 6192 & Nil \\
\hline Total & 100 & 100 & & & 19804 & 117802 \\
\hline
\end{tabular}

The domestic waste abounds in organic waste including food waste and its content becomes higher in rainy season than that in dry season. The food waste portion varied on average from $70 \%$ in dry season to $75 \%$ in wet season. The organic waste (paper, food waste, wood and grass) appears more than $80 \%$ in the domestic waste throughout the year. 
The percentages of plastics increased upto $7 \%$ in wet season from $5 \%$ in dry season. The total percentages of recyclable and non-recyclable wastes were $14.38 \%$ and $85.62 \%$ respectively. Due to the rainfall the demand of plastics, polythene increases and at the same time paper products demand decreases. The percentages of garden waste decreases in the wet season.

\subsection{Moisture content}

Moisture content is the measure of the amount of water retained by the waste elements. It depends on the percent of pore space presents in the element. The elements with higher percentages of pore space contain more moisture. Most of the samples of rainy season show higher value than dry season as shown in Fig. 2.

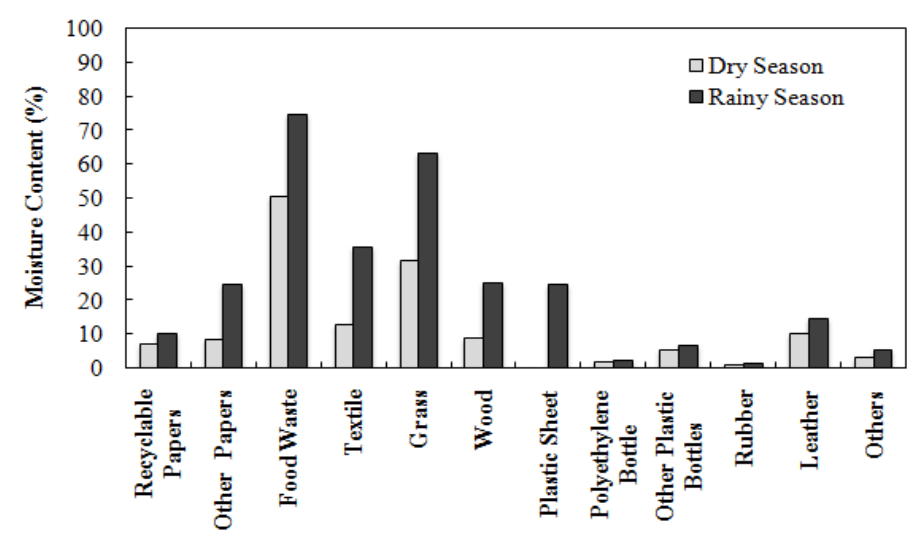

Fig. 2. Moisture contents of the constituents of incoming solid wastes at Amin Bazar waste dumping site.

Heating values of solid wastes depend on the types of wastes and moisture contents of the wastes. Themelis et al. [12] reported that the heating values of the different types of wastes decrease as the moisture content increases. Based on the moisture contents, the calorific value of the solid waste generated in Dhaka city was estimated $8.0 \mathrm{MJ} / \mathrm{kg}$ [13]. So, there is a huge prospect of producing electricity from the waste.

\section{4. $\mathrm{pH}$}

$\mathrm{pH}$ is a term used universally to express the intensity of the acidity or alkalinity. It is a measure of hydrogen ion concentration or more precisely the hydrogen ion activity. The collected samples were analyzed for $\mathrm{pH}$ determination. The following Table 3 represents the $\mathrm{pH}$ values of the samples. The range of $\mathrm{pH}$ of the samples was from 6.9 to 7.8 with an average 7.47 which indicates the neutral condition. 
Table 3. The $\mathrm{pH}$ value of the wastes at Amin Bazar waste dumping site.

\begin{tabular}{cccc}
\hline & $\mathrm{pH}$ & & \\
\cline { 1 - 3 } Sample 1 & Sample 2 & Sample 3 & Average \\
\cline { 1 - 3 } 7.5 & 7.5 & 7.8 & 7.6 \\
7.6 & 7.6 & 7.8 & 7.7 \\
6.9 & 7.2 & 7.8 & 7.3 \\
7.2 & 7.4 & 7.3 & 7.3 \\
7.1 & 7.5 & 7.6 & 7.4 \\
7.3 & 7.5 & 7.4 & 7.4 \\
7.8 & 7.6 & 7.5 & 7.6 \\
7.5 & 7.7 & 7.5 & 7.6 \\
\hline
\end{tabular}

\subsection{Economic prospects of the waste management}

\subsubsection{Recycling of wastes}

Recycling is the most important practice of solid waste management. Materials recovered from solid waste can be used as resources or as raw materials for the new production. The main recyclable wastes and recycled products are aluminum, ferrous metals, paper and cardboard, glasses and plastics. The Amin Bazar waste dumping site annually received 196 tons of aluminum and ferrous metals, 4816 tons of paper and cardboard, 8256 tons of plastics and 344 tons of glass materials. These can be used as resources. The proper recycling process of them can provide a large income source. The Table 4 indicated the economical payback of wastes from recycling processes.

Table 4. The economic benefits of recycling of waste materials.

\begin{tabular}{cccc}
\hline $\begin{array}{c}\text { Recyclable } \\
\text { Commodity }\end{array}$ & $\begin{array}{c}\text { Annually Generated } \\
\text { Amount (Tons) }\end{array}$ & $\begin{array}{c}\text { Price per } \\
\text { Ton } \\
\text { (BDT)* }\end{array}$ & $\begin{array}{c}\text { Total price } \\
\text { (BDT) }\end{array}$ \\
\hline Metals & 196 & 20000 & 3920000 \\
Papers and & 4816 & 12000 & 57792000 \\
Cardboard & 344 & 5000 & 1720000 \\
Glass & 8256 & 6000 & 49536000 \\
\hline Plastics & 13612 & & 112968000 \\
\hline Total & & &
\end{tabular}

* From the local market

Waste recycling has some significant advantages. If the waste can be recycled properly, it will be possible to earn around Bangladeshi Taka (BDT) 112.9 million in every year. Now a day these commodities are collected by the waste pickers and sell in the local market. The polythene or plastic products are recycled by a group of people and sell in the local market. 


\subsubsection{Composting of waste}

Compost is organic material that can be used as a soil amendment or as a medium to grow plants. Mature compost is a stable material with content called humus that is dark brown or black and has a soil-like, earthy smell. It is created by: combining organic wastes (e.g., yard trimmings, food wastes, manures) in proper ratios into piles, rows, or vessels; adding bulking agents (e.g., wood chips) as necessary to accelerate the breakdown of organic materials; and allowing the finished material to fully stabilize and mature through a curing process. Three types of composting are typical and can produce 0.25 tons of compost from 1.0 tons of organic waste [14]. The total amount of organic wastes (99075 ton) received by Amin Bazar dumping site in one year can produce 24768 tons of composts. The price of per kilogram compost is minimum BDT 3.5 in the local market and therefore it is possible to make BDT 86.7 million every year if the organic wastes of the incoming site are properly composed.

\section{Conclusion}

The amount of solid waste generation is large in Dhaka. The present solid waste dumping system is neither environment friendly nor sustainable. Unplanned dumping of solid waste poses severe health hazard as they often contain pathogenic microorganisms. The runoff pollutes aquatic ecosystems. The solid waste management system of DCC is not sufficient to manage the up growing problem of solid waste. So, government should take some necessary steps in this regard by providing proper management authority and effective action plans. Importance should be given in recycling and composting which is a source of income as well as sustainable environmental management.

The solid waste is a solid resource if the wastes are managed properly. Annually 112.9 million BDT can be earned from the waste of the site if the wastes are recycled properly and annually 86.7 million BDT can be earned from the organic waste if the wastes are composted properly. The total amount of income will be 200 million BDT if the wastes are properly managed. There should be more emphasis on recycling and composting of the wastes. Through these processes it is possible to get economical benefits as well as sustainable environmental management. By ensuring the availability of skills, knowledge, and capacity to implement waste management programs effectively, especially at the local level, it is possible to turn the solid waste into the solid gold.

\section{References}

1. M. Alamgir, W. Bidlingmaier, U. Glawe, J. Martens, I. A. Sharif, C. Visvanathan, and W. Stepniewski, in Safe and Sustainable Management of Municipal Solid Waste in Khulna City of Bangladesh - 11th Int. Waste Management and Landfill Symp. (Cagliari, Italy, 2007).

2. H. Wang and Y. Nie, J. Air Waste Manag. Assoc. 51(2), 250 (2001). http://dx.doi.org/10.1080/10473289.2001.10464266

3. M. Sharholy, K. Ahmad, G. Mahmood, and R. C. Trivedi, Waste manag. 28(2), 459 (2008). http://dx.doi.org/10.1016/j.wasman.2007.02.008 
4. $\quad$ S. Rathi, J. Waste Manag. 26(10), 1192 (2006).

http://dx.doi.org/10.1016/j.wasman.2005.09.006

5. S. Sharma and P. Malaviya, Int. J. Environ. Sci. 2(3), 114 (2013).

6. A. Ahsan, M.Sc Thesis: Generation, Composition and Characteristics of Municipal Solid Waste in Some Major Cities of Bangladesh (Department of Civil Engineering, Khulna University of Engineering and Technology, Bangladesh, 2005).

7. A. Ahsan, M. Alamgir, R. Islam, and K. H. Chowdhury, in Initiatives of Non- Governmental Organizations in Solid Waste Management at Khulna City- Proc. $3^{\text {rd }}$ Annual Paper Meet and Intl. Conf. on Civil Eng. (IEB, Dhaka, Bangladesh, 2005) pp. 185-196.

8. F. Farzana and M.A. Kabir, Khulna Univ. Studies 4, 725 (2004).

9. R. Gupta and A. K. Misra, Adv. Energy. Eng. 2, 30 (2014).

10. Japan International Cooperation Agency (JICA), Clean Dhaka Master Plan, Final Report, Pacific Consultants International, Yachiyo Engineering Co., Ltd. (2005).

11. F. I. Hai, and M. A. Ali, UAP J. Civ. Environ. Eng. 1(1), 18 (2005).

12. N. J. Themelis, Y. H. Kim, and M. H. Brady, Waste Manag. Res. 20(3), 223 (2002). http://dx.doi.org/10.1177/0734242X0202000303

13. M. A. Sufian and B. K. Bala, Waste Manag. 27(7), 858 (2007). http://dx.doi.org/10.1016/j.wasman.2006.04.011

14. I. Enayetullah, and Q. S. I. Hashmi, in Community Based Solid Waste Management through Public-Private-community Partnerships: Experience of Waste Concern in Bangladesh - 3R Asia conf. (Tokyo, Japan, 2006). 